KRISTÓF Péter

\title{
A MUUKOÖDÉSI STRATÉGIA ÉS A TECHNOLÓGIAI INNOVÁCIÓ KAPCSOLATA
}

\begin{abstract}
A technológiai innovációra építő vállalatoknak rugalmas múködési struktúrával kell rendelkezniük ahhoz, hogy a gyorsan változó piaci igényeket ki tudják elégíteni és versenyben tudjanak maradni, hiszen ezen a téren naponta jelennek meg új megoldások és válnak váratlanul piacvezetôvé. Mindezek a mozgások alapjaiban rendezik át a piacot és okoznak kellemetlen meglepetéseket korábban stabilnak hitt vállalkozásoknak. A dolgozat bemutatja, miként lehetséges gyors alkalmazkodási képességre szert tenni, és milyen múködési stratégiát javasolt a technológiai innovációk jelentette kihívások kezelésére kidolgozni. Szól továbbá arról, hogy a múködési stratégia megvalósításához hogyan érdemes az ellátási láncot megszervezni, és hogy milyen elốnyök származnak a gyártási kapacitás saját kézben tartásából. A tanulmány átfogó képet ad a kapcsolódó szakirodalomról és kitekintést nyújt a tendencia várható alakulására. Mindezt napjaink meghatározó technológiai vállalatainak példáin keresztül teszi szemléletessé.
\end{abstract}

Kulcsszavak: múködési stratégia, technológiai innováció, ellátási lánc, fenntartható versenyelóny, gyártási kompetencia

„Innovation distinguishes between a leader and a follower." (Steve Jobs)

Az olyan nagyvállalatok, mint az Apple, az Intel, a Corning vagy az Amazon hamar felismerték, hogy a folyamatosan növekvő vevối igényeknek történô megfeleléshez az innováció, a marketing és a gyártás kiemelt kezelésére van szükség, és az élen maradáshoz nélkülözhetetlen a technológiai elóny fenntartása, aminek egyedüli eszköze a megkülönböztetô erejú tervezési és gyártási kapacitásokba történő befektetés. Mindez egyet jelent a cselekvési horizont kibővítésével, a tőzsdei befektetők rövid távú szemléletének megváltoztatásával, valamint a fogyasztói igényeket középpontba állító, fókuszált kutatás-fejlesztési tevékenység kialakításával (Pisano - Shih, 2009). Az így létrehozott képességek lesznek azok, amelyek által a vállalatok olyan új termékeket tudnak kifejleszteni, amelyeket a fogyasztók elfogadnak, értékelnek és megfizetnek (Cash - Earl - Morison, 2008). A gazdasági tevékenység hatékonyságának, jövedelmezőségének ilyen módon történó javítása érdekében végzett tudományos, múszaki, szervezési, gazdálkodási és kereskedelmi múveletek eredményeként rendszeresen új termékek, eljárások, szolgáltatások jönnek létre, amelyek hosszú távon is képesek egy vállalkozás versenyelőnyét biztosítani (Hoffer - Katona, 2012).

A következókben bemutatom, miként lehet innovatív megoldásokra sikeres vállalatot építeni, azok múködtetésének milyen sajátosságai vannak, és az általuk kínált termékek előállításának és a szolgáltatások nyújtásának mik a jellegzetességei. Az elméleti megállapításokat sikeres nagyvállalatok példáival szemléltetem.

\section{Az ötlettól a piacig}

Innovatív megoldásokat kínáló vállalkozások múködtetésének és irányításának - más vállalatokhoz hasonlóan - egy stratégia alapján kell végbemennie, de nem szabad, hogy ennek megalkotása szokások és berögző́dések mentén történjen, mert az a legtöbb esetben csalódáshoz vezet (Anthony - Eyring - Gibson, 2006).

Az innovációval kapcsolatos kihívások minden szervezetben másként jelentkeznek, így kezelésük sem lehet azonos. A vezetốknek fel kell ismerniük vállalatuk gyengeségeit, és az elérhetố legjobb gyakorlatokat ezek megszüntetésére kell felhasználniuk. Ennek egyik eszköze az innovációsértéklánc-szemlélet, amely az

\section{VEZETÉSTUDOMÁNY}


említett gyengeségek beazonosítása mellett az ötlettől a piacra vezető út szegmentálását is segíti (Hansen Birkinshaw, 2007).

Az elképzelés Michael Porter értéklánc-elméletén alapszik (Porter, 1985), de kifejezetten az innovációkkal foglalkozik. Az innovációt egy soros, három lépésbôl álló folyamatnak tekinti, mely az ötlet létrejöttétól indul, és annak termékké/szolgáltatássá alakításán át a széles körben történó elterjedéséig vezet. Az elmélet hat fontos feladatot definiál (belsô, külsô és szervezeti egységek közötti együttmúködés, megfelelő ötletek kiválasztása és továbbfejlesztése, majd ezek elterjesztése), a lánc gyenge szemeire, a folyamat szúk keresztmetszeteire koncentrál, ezek kezelésére ad általános megoldásokat, megközelítési módokat, és egyúttal óva int más vállalatok innovációs gyakorlatának másolásától - a vállalatok innovációs környezete és kihívásai ugyanis egyediek.

Az értéklánc alkalmazhatóságának egyik kiváló példája az Apple iPhone-ja. A termék koncepciójának megalkotása (az ötlet létrejötte) apró elemekből történt (LCD érintôképernyô, védőuiveg, gyorsulás-, közelségés fényérzékelő, mobil operációs rendszer), amelyek akkor (a 2000-es évek közepén) már kellóen alacsony áron elérhetóek voltak a piacon, de senki sem illesztette azokat össze úgy, mint Steve Jobs és csapata. A siker elsôsorban a gyártó egymástól távol esô, egymással kevésbé kommunikáló részlegeinek együttgondolkodása és együttmúködése során született meg, aminek folyamán a résztvevốk legalább annyi ötletet gyújtöttek a vállalaton kívülról, mint a falakon belülról, továbbá képesek voltak ezeket fókuszálni, amihez a vállalat megfelelő nagyságú tókét tudott allokálni. A siker további tényezőit a magas minőségú termék, a karcsúra szabott gyártási folyamat megtervezése és a korszerú marketingeszközök bevetése jelentették.

Az innovációs értéklánc alapján végzett termék/szolgáltatásfejlesztés három ponton is kudarcot vallhat (Hansen Birkinshaw, 2007):

1. ötletszegény környezet: egy ötletszegény vállalat hiába fordít nagy összegeket új ötletek generálására, azok mégsem születnek meg,

2. megvalósítási nehézségek: hiába a jó ötlet, ha azt nem sikerül termékké vagy szolgáltatássá fejleszteni, bár az ötletek megszületnek, azok továbbgondolása zsákutcába vezet, amin a vállalkozás markáns veszteséget realizál,

3. gyenge értékesítési képesség: megvan a jó ötlet, abból létrejön a piacképes termék, de a gyenge értékesítési képesség miatt az eladás kudarcot vall.

A termék gyártási folyamatának megszervezése további dilemma elé állítja a döntéshozókat. Miként dönthetô el, hogy a gyártás saját kézben tartása nélkülözhetetlen a további innovációhoz, vagy hosszú távon is gazdaságosabb azt kiszervezni? Erre a kérdésre a gyártási folyamat érettségi szintjének és a kutatás-fejlesztési folyamat modularitásának vizsgálatával kaphatunk választ.

A gyártási folyamat érettsége attól függ, hogy a gyártási technológia a kidolgozása óta mennyit fejlődött. Magas érettség esetén a gyártási folyamat továbbfejlesztésére már kevés lehetôség kínálkozik. A modularitás szintje pedig az alapján határozható meg, hogy a terméktervezóknek milyen ismeretekkel kell rendelkezniük a gyártási folyamatról - azaz a tervezés és a gyártás milyen szinten kapcsolódik össze. Magas szintú modularitás esetén az előállított termék tulajdonságai kevésbé függnek a gyártási eljárástól. A két tényező alapján az 1. táblázatban látható esetek fordulhatnak elő (Pisano - Shih, 2012).

\section{Modularitás - Érettség mátrix}

1. táblázat

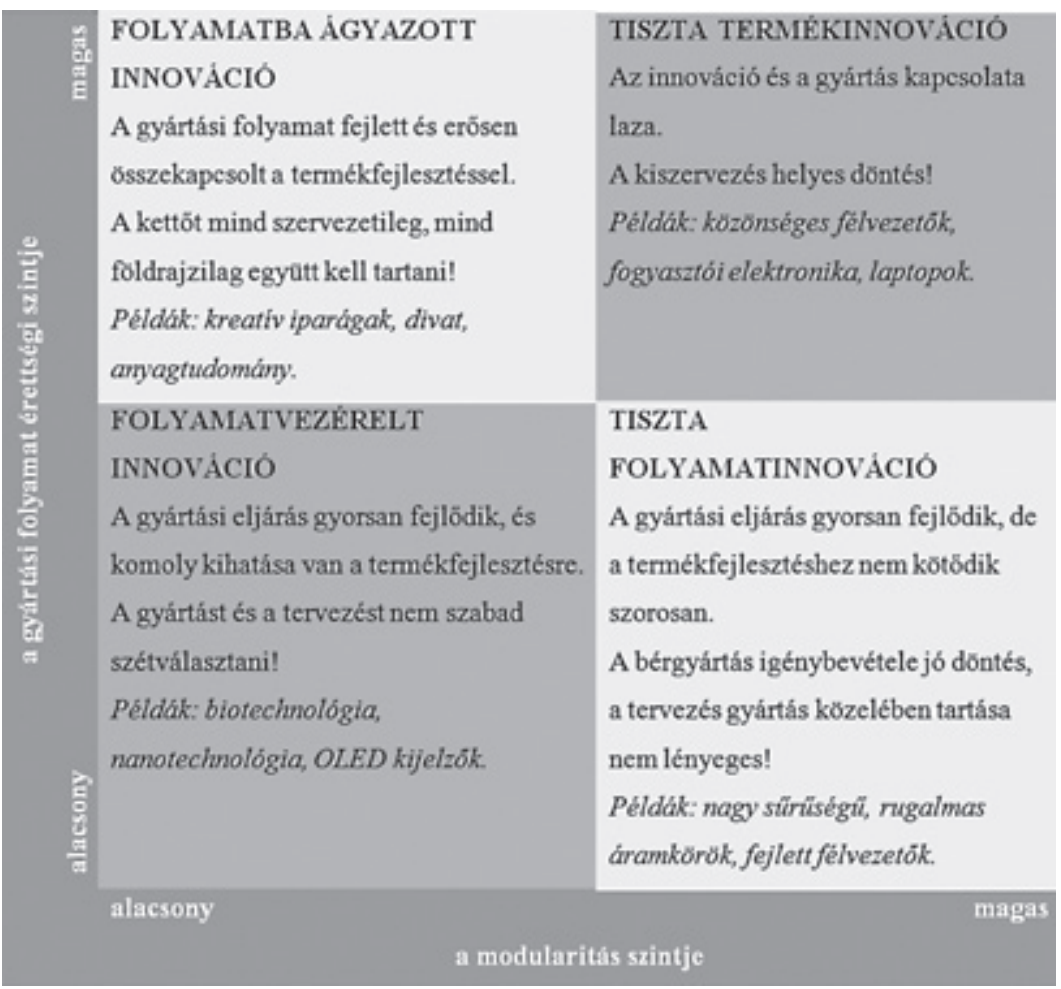

Forrás: Pisano - Shih (2012) alapján saját szerkesztés 
Az értékláncszemlélet megfelelő alkalmazásával, valamint az adott vállalkozás fenti mátrixban történô elhelyezésével mind az innovációs képesség személyre szabott megmérése, majd a kapott eredmények alapján a szükséges intézkedések meghozatala, mind pedig az innovációs stratégia megalkotása és megvalósítása is lehetségessé válik. A kiszervezéssel kapcsolatos döntésnél azt is figyelembe kell venni, hogy a gyártás falakon kívülre helyezése gyakran egyirányú utca: ha a kiszervezés megtörtént, a legritkább esetben van visszaút, azaz a tevékenységek visszaszervezése legtöbbször nem lehetséges - pont az elveszített tudás hiánya miatt.

Az Apple e területeken sikerrel vette az akadályokat és találta meg az egészséges egyensúlyt: a gyártás kiszervezésével nem ásta alá saját innovációs képességeit, a terméktervezést magánál tartotta, és több termékével is képes volt néhány év alatt piacvezetôvé válni.

\section{A gyártási megoldások és az innovációs stratégia kapcsolata}

A legtöbb technológiai újdonság önmagában nem sokat ér - szükség van olyan kiegészítő funkciókra, amelyek értékessé, vonzóvá és eladhatóvá teszik azokat. A sikerhez a vállalat stratégiájával összhangban kialakított és múködtetett innovációs ökoszisztéma szintén nélkülözhetetlen. Az innovációs ökoszisztéma ebben a megközelítésben az a tér, ahol a közösségi és az üzleti elképzelések egymásra találnak. Az Apple példájánál maradva: az iTunes on-line zenebolt tervei a piaci megjelenésnél már évekkel korábban elkészültek, a cég mégis kivárt addig, amíg az internetes zeneértékesítés körüli szerzői jogi kérdések tisztázódnak és a piac fenntarthatóvá, az erre épülő üzlet pedig megtérülővé válik (Adner, 2006).

Az újdonság által hordozott kockázatok úgy is csökkenthetôk, hogy egyszerúbb megoldásokat kínálunk, kisebb vagy jobban szegmentálható piacokon. Ugyanakkor a kockázatok mérhetővé tétele életszerú elvárások megfogalmazását is lehetővé teszi, ami végső soron végrehajtható stratégiához és sikeres innovációkhoz vezet.

Michael Porter szerint a stratégia egyedi (mondhatni: innovatív) tevékenységeken alapszik. Valamiben másnak kell lenni, mint a versenytársak - és minél inkább mások vagyunk, annál inkább képesek leszünk vevőink számára egyedi értéket nyújtani. Mindezek alapján a stratégiai versenyelőnynek három forrása határozható meg (Porter, 1996):

1. választékalapú stratégiai pozicionálás: amikor egy iparág egy fontos termékének, alapanyagának gyártására szakosodunk,

2. igényalapú stratégiai pozicionálás: amikor egy piaci csoport minden igényét lefedjük,
3. hozzáférés-alapú stratégiai pozicionálás: amikor vevőinket szegmentáljuk, és megoldásainkkal az így létrejött csoportok igényeit egyedileg szolgáljuk ki.

A stratégia mindezek alapján úgy definiálható, mint egy egyedi és értékes pozíció különféle tevékenységekkel történô létrehozása és megtartása (Porter, 1996). A legjobb stratégiák az egyedi képességekre és adottságokra, és nem az ingatlanokra vagy a felszerelésekre fordított beruházásokra épülnek, megvalósulásukat pedig a kívánt képességek megszerzését lehetővé tévő tervek végrehajtása jelenti (Hayes - Pisano, 1994). A stratégia így a vállalat egymást erôsítő tevékenységeinek megtalálásáról és egyedi összerendeléséról szól, az iparági versenyben pedig az azonosított kompetenciákat kell a középpontba helyezni és felhasználni (Porter, 1996).

Az Apple képes volt egyrészt gyártási és innovációs stratégiáját ezek figyelembevételével megalkotni, másrészt sikerre vinni, továbbá a piaci igények és a technológiai kihívások változásával azokat folyamatosan módosítani és naprakészen tartani. Az így megvalósított növekedés tehát nem mennyiségi változás volt, hanem egy olyan új kínálat megjelenése, amely minóségi ugrást (quantum leap) eredményezett (Dobák Hortoványi - Szabó, 2012), és a gyakorlatban a vállalat több évtizedes múltja során felhalmozódott tervezési, gyártási, mérnöki és marketingismeretek összeillesztését, és az így létrehozott, megkülönböztető és egyedi tudáshalmaz jövőorientált fókuszálását jelentette. A gyártásnak csak a legalacsonyabb hozzáadott értékkel bíró részeit szervezték ki, így a folyamatos megújuláshoz, valamint a termékeik rendszeres megújításához szükséges tudást képesek voltak megórizni és vállalaton belül tovább kamatoztatni.

\section{Stratégiába ágyazott megújulási képesség}

Egy tőzsdén jegyzett vállalkozás számára rendszeresen elérendő mérföldköveket jelentenek a stratégiában meghatározott havi és negyedéves tervek és mutatószámok. Ha ezek sorozatban nem teljesülnek, mind a vezetốk, mind a befektetốk türelmetlenekké válnak, ami megnehezíti a hosszú távú tervezést. A rövid távú múködési nehézségek kiölik a szervezetből a stratégiáról folytatott párbeszédet, ami lehetetlenné teszi annak felülvizsgálatát, módosítását és a kiút megtalálását. A problémák legtöbbször a vezetési rendszer (értve ezalatt a stratégia megfogalmazásához és annak lefordításához használt folyamatok és eszközök összességét) elégtelenségeiben, és nem a vezetốk személyes képességeiben keresendók. Kaplan és Norton éppen az ilyen helyzetek megelőzésére dolgozta ki ötfázisú vezetési 
modelljét, amely képes a vállalati stratégia és a mindennapi múködés közötti kapcsolat megteremtésére. Ebben az öt fázis egymásutánisága egy önmagába viszszatéró, zárt ciklust alkot (Kaplan - Norton, 2008):

1. A stratégia kidolgozása és megfogalmazása: az üzleti feltételezések átvizsgálása és a versenyhelyzet megismerése, valamint annak a kérdésnek a megválaszolása, hogy a vállalkozás milyen iparágban tevékenykedik és miért. Ebben a szakaszban történik a küldetés és a vízió meghatározása, továbbá a belsô értékek feltárása.

2. A stratégia lefordítása napi szintü teendókre: olyan célok kijelölése és mérôszámok meghatározása, amelyekkel a stratégia elmagyarázható a munkatársak számára. Ennek egyik eszköze a stratégiai térkép, amely a stratégiai célok közötti ok-okozati összefüggéseket ábrázolja. A hangsúly az előrehaladás mérésén van - csak így lehetséges annak követése és irányítása.

3. A napi szintú teendók megtervezése: a stratégiai célok elérését lehetővé tevő (operatív) terv kidolgozása és kivitelezése. Az üzleti folyamatok fejlesztése, valamint a részletes értékesítési és erőforrás-felhasználási tervek, a múködési és a tôkeköltségvetés összeállítása történik ebben a lépésben. Előállnak azon kritikus sikertényezók és mérôszámok, amelyek elérése a dolgozók mindennapi tevékenységeinek elvégzése által történik.

4. Elemzés és tanulás: az elmúlt idôszak teljesítményének értékelése, a problémák azonosítása, az üzleti (balanced scorecard) indikátorok áttekintése, a stratégiai cél irányába tett előrehaladás mértékének meghatározása alkotja e lépés legfontosabb feladatait.

5. A stratégia ellenórzése és módositása: az utolsó lépésben az aktuális gazdasági helyzet elemzésére, a stratégia elérését mutató mérôszámok közötti összefüggések feltárására és új stratégiai elemek alkalmazhatóságának vizsgálatára kerül sor.

A szervezeteket legjobban az általuk megtermelt termékek vagy nyújtott szolgáltatások jellemzik. A termék kifejezi a szervezet képességét, meghatározza fogyasztóit és versenytársait, továbbá beazonosítja a meglévő vagy az elérendő kompetenciákat. A vállalaton belüli változások kezdeményezésének legfontosabb hajtóereje az új termék létrehozásának szükségessége, mely megújíthatja a szervezetet, és új technológia kifejlesztésére vagy új kompetencia megszerzésére ösztönöz. A termék és a termelési folyamat fejlesztése új képességek megszerzését teszi lehetővé, új eszméket honosít meg, megkérdőjelezi a hagyományos gondolkodást és ledönti a vélt vagy valós korlátokat - azaz a fejlődés bölcsôjeként és a stratégia alapjaként funkcionál (Vörös, 2010).

Ugyanakkor hiába rendelkezik egy vállalat a legjobb stratégiával, egészen addig nem fog tudni előrejutni, amíg azt a vezetốk le nem fordítják mindennapi tervekre és tevékenységekre, és nem hajtják azokat végre, elérve egyúttal a lefektetett célokat. A fent ismertetett lépések folyamatos ismétlése támogatja a stratégiai célok kijelölését, a megfelelő erőforrások hozzárendelését, a döntések hatásainak követését és a stratégiai célok felülvizsgálatát. Ezen döntések középpontjában sokszor kiszervezéssel kapcsolatos dilemmák állnak (Kaplan - Norton, 2008).

\section{Kiszervezési dilemmák - mikro- és makroszinten}

Az Apple legkeresettebb eszközei mind magas tudástartalmú termékek. A gyártás megtervezése és megszervezése minden vállalatot kemény kihívás elé állít, amelyet a szellemi jogok tulajdonosa sokszor bérgyártás segítségével kíván megoldani, azaz a gyártást kiszervezi, a kutatás-fejlesztést és a marketinget (beleértve az értékesítést is) pedig saját maga végzi. Bár a gyártás során a költségek alacsony szinten tartása fontos, kiemelten mégis a minóséget kezelik. Az almás cég mérnökei az iPhone megalkotásával a (mobil) telefont kívánták újraértelmezni, ugyanakkor a kiszervezéssel nem szerették volna elveszíteni azt a tudást, ami a gyártási folyamatok tervezése és irányítása hordoz. Tisztában voltak azzal, hogy a kollégáik között múködő tudáshálózat kulcsszerepet játszik jövôbeli sikerességükben, aminek fenntarthatóságát egy esetleges kiszervezés jelentősen megnehezítheti (Pakucs - Papanek, 2006). Hét év távlatából állíthatjuk, hogy mindkét céljukat sikerült elérniük.

A stratégia gyártási folyamatokra történô lefordítása nem jelentheti csupán azok javítását, tökéletesítését. Más szavakkal azt is mondhatnánk, hogy a minőség javítása (pl. TQM vagy JIT bevezetése által) önmagában még nem stratégia. A stratégia sokkal inkább azon versenyelőny meghatározását és kijelölését jelenti, amelynek eléréséért és azt követően annak megtartásáért a vállalkozás küzd. Ezen túlmenően a minôség, a fogyasztói elégedettség és az elérhetô profit közötti szoros összefüggés felismerésére is szükség van - mint ahogyan ezt a Toyota 1960-as évekbeli példája is alátámasztja (Cole, 2011). Az autógyár a JIT bevezetésével tulajdonképpen egy olcsó, problémamentes, kiegyensúlyozott, hirtelen reagálni képes, magas minőségú gyártási folyamatot hozott létre, amely késóbb etalonná vált (Vörös, 2006), az Apple pedig külsóleg támogató termelési képességre tett szert, ami forradalmasította 
az iparágat, vadonatúj eljárásokat hozott létre, áttörve egyúttal a korábban korlátként kezelt termelési határokat (Wheelwright - Hayes, 1985).

Ebben a megközelítésben a beruházások (gyártási kapacitásba, emberi eróforrásba, tudásba) biztosítják a piacvezető pozíció eléréséhez és megtartásához szükséges képességeket. E képességek értéke (a reálopciós szemlélet alapján) a jövőben növekvô bizonytalansággal együtt növekszik, ami által az ezekbe történő befektetés megtérülési ideje rövidül. Ha például ma még nem tudjuk, hogy néhány év múlva a vevőink az alacsony árat vagy a magas minóséget fogják jobban megfizetni, akkor ma a jövőbeli rugalmasságot biztosító képesség kifejlesztésébe történő beruházás a helyes stratégia. Minél inkább kiszámíthatatlan a jövő, annál inkább kifizetődő lesz ez az út (Hayes - Pisano, 1994).

Mindezek ellenére, amikor a vállalatok a gyártási folyamatok és tevékenységek megszervezésével kapcsolatos döntéseiket hozzák, szinte kizárólag pénzügyi mutatókra támaszkodnak, a döntés következtében pedig azok kedvezô alakulását kívánják elérni. A legtöbbször egy valamiról szinte mindig megfeledkeznek: mennyit ér a gyártási folyamatok saját kézben és a fogyasztói piac közelében tartása - és nem számolnak azzal, hogy a gyártáshoz kapcsolódó képességek megléte és fejlettsége szoros kapcsolatban áll az innovációs potenciállal, azaz az újító ötletek és megoldások nagyon sok esetben éppen a gyártási terület felól érkeznek. A kapcsolat a másik irányban is fontos: egy új ötlet kidolgozása és termékké fejlesztése szinte elképzelhetetlen a gyártási folyamatok közelsége nélkül (Pisano - Shih, 2009, 2012). Amellett, hogy a gyártási rendszer felépítése az aktuális vállalati teljesítményre is jelentős hatással van, a jövőben megszerezhetô képességeket is nagyban meghatározza. Ebben a megközelítésben a gyártási stratégia nemcsak a múködés aktuális piaci elvárásokhoz történő igazításáról szól, hanem arról is, hogy miként hozhatók létre azok a gyártási kompetenciák, amelyekre a jövoóben a vállalatnak szüksége lesz (Hayes - Pisano, 1994).

A gyártási tevékenység határokon belül tartása nemcsak egy vállalat, hanem egy nemzetgazdaság szempontjából is fontos: a rövid távú előnyökkel kecsegtetô, tömeges kiszervezéssel egy ország könnyen elveszítheti a következố generációs technológiai újdonságok létrehozásának képességét - ami egyúttal a gazdaság újjáépítésének alapjait is jelenti. A gondot nem önmagában a kiszervezés jelenti, hanem annak túlzásba vitele: amikor már nemcsak a legalacsonyabb hozzáadott értékkel bíró tevékenységek (mint például az összeszerelés) kerülnek a falakon kívülre, hanem a komoly mérnöki munkát igénylő feladatok is (mint például a tervezés). Egy ilyen folyamat végeredménye a teljes ellátási lánc kiszervezése is lehet, amire számos példát láthattunk a nyomtatott áramkörök, a félvezetók vagy a laptopok piacán (Pisano - Shih, 2009).

Az Egyesült Államokban a tömeges kiszervezések következtében a kutatás-fejlesztés és technológiaigényes gyártási tevékenységek és kapacitások (pl. LEDek, érintôképernyôs kijelzôk, akkumulátorok előállítása és továbbfejlesztése, alapszintú szoftverek fejlesztése) fokozatosan leépültek. Az így elvesztett tudás hiányát jó ideig eltakarta a növekvő jólét. A leplet - évek múltán - a gazdasági válság rántotta le. Azt, hogy a fizikai közelség (különösen a tudásintenzív iparágakban) igenis számít, és hogy változásra van szükség, nemcsak az ország vezetői ismerték fel, hanem a technológiai nagyvállalatok elsố emberei is: a folyamatok megváltoztatását addigi gyakorlatuk - ami a kiszervezéssel együtt járó előnyök felülértékelését és a kockázatok alulértékelését jelentette - felülvizsgálatával kezdték (Pisano - Shih, 2009).

Mindezek a kérdések az Apple-t is komolyan foglalkoztatják, hiszen világmegváltó ötleteik mind Cupertinoban születnek, de azok kínai gyártósorokon keresztül jutnak el fogyasztóikhoz, felhasználóikhoz. Mindezt a termékeikre írva is jelzik: „Designed by Apple in California. Assembled in China." Rajtuk is erős a nyomás, hiszen a tervezés kiszervezésével további megtakarításokat érhetnének el. Steve Jobs ezzel kapcsolatban azt nyilatkozta, hogy semmi esélyt nem lát arra, hogy ezen a jövốben változtatnának, azaz a gyártást nem viszik vissza Kaliforniába - hiszen ott nincs meg az a tudásbázis, ami ezt lehetôvé tenné -, de a tervezést sem viszik Kínába, mert azzal legfontosabb tudástôkéjüket tékozolnák el (Rawson, 2012).

A kiszervezéssel járó veszélyeket Tim Cook (aki Jobs halála után került az Apple élére) szintén felismerte, és 2012 nyarán már úgy nyilatkozott, hogy Mac számítógépeik egy típusának gyártását visszahelyezik az USA-ba, és erre százmillió dollárt fordítanak. Ráébredtek, hogy a gyártási tevékenység ellátásával együtt járó tudás nélkülözhetetlen inputokat biztosít termékeik továbbfejlesztéséhez, ezért a túlzott mértékú kiszervezés hosszú távon aláássa versenyképességüket (Denning, 2012), ami az innovációs képességükre is negatív hatással van (Kiss, 2005). Az emberekhez hasonlóan a vállalatok szintúgy elfelejtik azt a tudást, amit nem használnak. Bár az elfelejtett gyakorlati ismeretek felelevenítése rövid távon többletráfordításokat igényel, de hosszú távon elengedhetetlen a hiányzó, létfontosságú képességek megszerzéséhez (Hayes - Pisano, 1994). Ilyen értelemben a „külsô” tanulás révén megszerzett tudás az innováció szuikséges, a tudás piacképes kombinálása pedig annak elégséges feltétele (Hámori, 2012). 
A külföldre vitt kapacitások visszaszervezésével és az elvesztett tudás visszaszerzésével kapcsolatos kezdeményezéseket az Egyesült Államok kormánya komoly összegekkel támogatja: ráébredtek ugyanis, hogy a gyártói kapacitás fenntartása és múködtetése jelentős innovációs tényező, ami hosszú távon jókora versenyelőnyt képes biztosítani nemcsak a vállalat, hanem az ország egésze számára (Porter - Rivkin, 2012). Ezen intézkedés, valamint az Apple saját döntése nyomán a legújabb, Mac Pro nevet viselő asztali munkaállomás 2013 nyara óta már teljes egészében az Egyesül Államokban készül. Döntésükkel és tettükkel nemcsak saját tudásbázisukat bővítik, hanem példát is mutatnak az iparág többi vállalata (mint például az Amazon vagy a Cisco) számára, és hozzásegítik az országot a kiszervezések következtében elvesztett kapacitások újjáépítéséhez (Czégeni, 2013).

A gyártási folyamat köré szerveződő beszállítók és kutatóközpontok, az együttmúködő vállalkozások, valamint a termék vásárlói lüktető ökoszisztémát hoznak létre. Ennek tudatos formálása és továbbfejlesztése nagyfokú odafigyelést és jelentős eróforrásokat igényel, ugyanakkor mindez hosszú távon, a folyamatos megújuláson keresztül megtérül.

\section{Az ökoszisztéma kialakulása és múködése - az ellátási lánc hatékony szervezése}

A csúcstechnológiát képviselő iparágak (például az elektronika, az informatika vagy az autógyártás) élenjáró szereplői - a lean elvek egyre szélesebb körben történő alapelvvé válásával - egyre nagyobb mértékben vonták be korábbi beszállítóikat a tervezési folyamatokba, és azok így egyre meghatározóbb szerepet kaptak termékeik következő generációjának megalkotásában, valamint a gyártási folyamatok továbbfejlesztésében. Jellemző módon a korábbi, hierarchikus viszonyt felváltotta egy mellérendelt, hálózatos elvek mentén épülő, partneri kapcsolat, amiben az érdekek közössé váltak.

Mindezek a folyamatok és átalakulások globális szinten is egyre határozottabban éreztették hatásukat: mind több piacvezetô és jelentős szereplő kezdte el gyártási tevékenységét saját falain kívülre helyezni. Ugyanakkor a tervezést és az innovációt, a marketinget és a kereskedelmet, valamint az ezek szervezésével és hatékony múködtetésével kapcsolatos teendők ellátását a nagy gyártók rendre maguknál tartották. A vállalat határain kívülre kerülő részekkel való kapcsolattartás többleterôforrást és újfajta megoldásokat kíván, amiben az elektronikus adatcsere (EDI - electronic data interchange) meghatározó szerepet játszik. Az így létrejött olyan új koncepciókra, mint a gyors, pontos és hatékony válaszreakció, a tömeges személyre szabás, a karcsú és agilis gyártás, Fisher már 1997-ben felhívta az üzleti döntéshozók figyelmét. Ezek értelmében az innovatív, technológiai iparágak termékeinek terjesztéshez sajátos ellátási lánc szükséges, hiszen azok nehezen előre jelezhető kereslettel és rövid termékéletciklussal, ugyanakkor magas profitréssel rendelkeznek. E termékeknél előtérbe kerül az ellátási lánc piaci közvetítő funkciója, ami nagyban hozzájárul ahhoz, hogy a piacra kerülő termékek a vásárlók által igényelt tulajdonságokkal rendelkezzenek. A piaci igények kielégítéséhez rugalmasan reagáló ellátási láncra van szükség, ami megteremti a nagyfokú ingadozást mutató kereslethez történó gyors alkalmazkodási képességet (Fisher, 1997).

A tizenhét évvel ezelőtt tett megállapítások még tovább éleződtek, és ma már minden összeköttetésben áll mindennel, a leginkább meghatározó tendenciáknak pedig az ügyfél-intelligencia (customer intelligence) és a prediktív analitika (predicitve analytics) számítanak. Mindezek célja az ügyféligények (közel)jövôbeli alakulásának minél pontosabb előrejelzése, alapja pedig a nagy tömegben létrejövô adatokból kinyerhetô információ és tudás. Az úgynevezett ,,big data” koncepció lényege, hogy a nagy mennyiségben keletkezô adatokban rejlő információk feltárásával a vállalkozás komoly vagyonra tehet szert, aminek kinyerése hozzásegíti a lean és az agile módszertanok bevezetéséhez és múködtetéséhez (McAfee - Brynjolfsson, 2012). Ezek egyrészt képessé teszik a szervezetet a nagy sebességú és mélyreható változásokhoz történô gyors alkalmazkodásra (Kotter, 2012) és az ehhez legjobban illeszkedô ellátási lánc kialakítására és múködtetésére, másrészt pedig a múködésbeli innováció alapját is jelentik. A Wal-Mart, a Toyota, a Dell vagy az Apple innovatív múködési megoldásaikkal - a rendelések kiszolgálásával, a termékfejlesztéssel és az értékesítéssel -, valamint ezek rendszeres megújításával versenytársaikat úgy tudták maguk mögé utasítani, hogy azok még csak a közelükbe sem tudtak férkőzni (Hammer, 2004).

A múködési innováció ugyanakkor nem összetévesztendő a végzett tevékenységek (pl. gyártás, logisztika) folyamatos fejlesztésével. Az innováció teljesen új megoldások alkalmazását jelenti: olyanokét, amelyeket eddig senki sem használt vagy alkalmazott. Jó példa erre a Wal-Mart „,cross-docking” módszere, amivel forradalmasította az áruk beszerzését és elosztását: a beszállított árukat nem raktározták, hanem egyból kamionokra rakták és kiszállították az áruházakba. Ezzel jelentős költségcsökkentést tudtak elérni, aminek köszönhetôen áraikat tartósan alacsonyan tudták tartani. Ezzel az egyszerú, de mégis átütő ötlettel a Wal-Mart húsz év alatt képes volt árbevételét ezerszeresére növelni. A Wal-Marthoz hasonlóan a Dell üzleti modell- 
jével (Dell Business Model), a Toyota termelési rendszerével (Toyota Production System), a Progressive biztosítótársaság azonnali reagálásával (Immediate Response) vált piacvezetôvé, de múködési innovációik által az Eastern Electric, az IBM és a Shell is jelentős növekedést tudtak elérni (Hammer, 2004).

Mivel a múködési innováció a vállalatot egy teljesen új szintre emeli, ezért azt nem egy projektként, hanem egy olyan szemléletmódként és kulturális elemként kell kezelni, ami áthatja a teljes szervezetet. Mindez a legtöbb vezetố számára szokatlan, de ez az egyetlen módja a kiváló teljesítmény elérésének és fenntartásának (Hammer, 2004). Ez a fajta megközelítés a Wise és Baumgartner szerzôpáros által 1999-ben felvázolt jövő́kép (Wise - Baumgartner, 1999) beteljesedését is jelenti. A Mercer két alelnöke az ellátási lánc teljes újragondolását tanácsolta a vásárlói húség középpontba állítása és a vertikális integráció elmélyítése mellett:

- Az ellátási lánc újraértelmezésének lényege, hogy arra a vevő szempontjából kell tekinteni: minden, a termékkel végzett tevékenységét nyomon kell követni, a vásárlástól a használat végéig (például egy autónál annak lecseréléséig), és minden lehetséges ponton kapcsolatba kell vele kerülni. Mindez az üzleti modell újragondolását is igényli, hiszen a nyereség több kisebb tételből fog összeáll ni (alkatrészek, kiegészítók értékesítése, kapcsolódó pénzügyi, finanszírozási és tanácsadási szolgáltatások), nem csak az értékesítéskori árrésből.

- A vásárlói húség eléréséhez nem elegendố elsố osztályú terméket szállítani. Olyan szolgáltatási csomagra van szükség, ami lehetôvé teszi a termékhez köthetố minden további költség minimalizálását. Egy ilyen környezetben a cél nem feltétlen a legnagyobb piaci részesedés elérése, hanem a legfontosabb vásárlók húségének elnyerése és hosszú távú megtartása.

- Ahogyan az értékteremtés lehetôsége fokozatosan a vásárló irányába tolódott, úgy vált a terjesztési csatornák szervezése egyre fontosabbá. Az elmúlt két évtized legnagyobb változását az internet megjelenése és uralkodóvá válása okozta, amely olyan e-kereskedelmi óriások létrejöttét eredményezte, mint az Amazon vagy az eBay.

Megállapításaik értelmében azon vállalatok tudtak sikeresek lenni, amelyek jelentős mértékben voltak képesek vevőik irányába elmozdulni - kilépni a gyártósorok falain kívülre és közeli kapcsolatba kerülni a piaccal (ahonnan árbevételük származik) (Wise - Baumgartner, 1999).
Valójában az Apple sem tesz mást, mint hogy ellátási és értékesítési csatornáit ellenôrzés alatt tartja, azokhoz keveseket enged hozzá, az ezekben közremúködô partnereit megversenyezteti, magát pedig közel tartja mind a fogyasztóihoz, mind pedig a beszállítóihoz, akiktól rendkívül sok impulzust kap azzal kapcsolatban, hogy milyen irányban érdemes termékeit továbbfejlesztenie, valamint milyen új megoldásokkal kell a piacon megjelennie. Ezzel a magatartással tulajdonképpen egy globális és virtuális Akihabara-jellegú piacot tart fenn (Stalk - Webber, 1993).

Az ellátási lánc szervezésébe és múködtetésébe a beszállítókat is érdemes - a fenti eszközök segítségével - bevonni. A Cisco 2001-es példája megmutatta a technológiai iparágnak, hogy mennyire fontos az ellátási lánc teljes együttmúködôi ökoszisztémára kiterjedő, hatékony szervezése. A vállalat azért volt kénytelen 2,7 milliárd dollárnyi veszteséget elkönyvelni, mert kiderült, hogy óriási menynyiségú, felesleges készletet halmozott fel, aminek oka az volt, hogy beszállítóinál túlzott mértékben jutalmazta a gyors rendelkezésre állást. A cég csak később ismerte fel, hogy a jelentôs veszteség a beszállítókkal történó szorosabb együttmúködés által elkerülhetố lett volna (Narayanan - Raman, 2004). A Cisco esete mindenki számára intô jel az ellátási rendszerek megtervezése és múködtetése során. A saját partnerektől, a szorosan együttmúködő alvállalkozóktól ötletek sokasága származhat, amelyek megkönnyíthetik eddig nem ismert összefüggések felismerését és meg nem hódított piacok feltárását.

\section{Új piacok felfedezése és meghódítása}

A piacvezetői pozíció elnyeréséért versenyző vállalkozások stratégiájának középpontjába a meglévô termékek és szolgáltatások továbbfejlesztése helyett új piacok létrehozását érdemes állítani. Ennek legfontosabb eszköze a folyamatos megújulás és az innováció, aminek következtében olyan termékek és szolgáltatások születhetnek, amelyek piaca korábban még nem létezett, így azon versenytársak sincsenek. Az értékbeli innovációk megvalósításához azonban a megszokottól eltérô gondolkodásmód szükséges, ugyanis csak ezáltal lehetséges korábban még meg nem hódított piacok felfedezése (Kim - Mauborgne, 1997).

Erre ad szemléletes példát a Sony, ami a Walkmannel létrehozta a hordozható zenelejátszók iránti keresletet. A Walkmant először a CD-t lejátszani képes discmanek, majd a flash memórián alapuló mp3-lejátszók forradalmasították. Az Apple az iPod 2001-ben történó bemutatásával erre a piacra lépett be, ahol az 
iPod csak egy volt a sok digitális formátumú zenét lejátszani képes eszköz között. Az igazi áttörést az iPoddal szoros szimbiózisban élő, 2003-ban megnyitott iTunes zenebolt hozta el. Az iTunes tette először lehetôvé, hogy egyetlen helyról, nagy tételben, viszonylag olcsón (1 dollár/zeneszám, 10 dollár/album) és legálisan lehessen zenét (szerzói jogilag védett hanganyagot) letölteni. Az Apple e megoldásával egy teljesen új piacot teremett. Ma 26 millió tétel érhetô el rajta keresztül, a fennállása során eladott tételszám pedig meghaladja a 25 milliárdot. Mindez az on-line zenepiacon 64\%-os, a teljes zenepiacon pedig 29\%-os részesedést jelent.

Az iTunes megjelenésével az Apple-nek ez volt az elsô (igen sikeres) kísérlete arra, hogy kihasználja az úgynevezett platformhatást. A platform ebben az értelemben egy olyan közeg, ami azáltal teremt értéket, hogy összekapcsolja az egymástól egyébként független fogyasztói csoportokat. Minél többen vesznek részt a hálózatos elvek mentén szerveződő platform múködtetésében, az előállított érték annál nagyobb lesz.

Az Apple az iPod-iTunes platformon keresztül közvetlenül kapcsolta össze a felhasználókat a szerzói jogok tulajdonosaival. Ezt a platformot bóvítette tovább az iPhone és az AppStore 2008-as megjelenése, ami a korábbi, kétoldalú platformot újabb szereplóvel bóvítette: az alkalmazásfejlesztókkel, akik csak az AppStore-on keresztül juthatnak el a vásárlókig, az Apple pedig 30\%-os részesedést kér minden értékesítésból (Osterwalder - Pigneur, 2010). Egyedi platformjának megteremtésével az Apple egy új részpiacot teremtett magának, amelyet aztán néhány év alatt elsődleges piaccá fejlesztett - és nem meglepó módon ennek piacvezetôi szerepét végig magánál tartotta.

\section{Következtetések}

A technológiai és a múködési innováció kéz a kézben járnak. Áttörố újdonságok kigondolása, megtervezése és sikeres piacra vitele elképzelhetetlen rugalmas szervezeti struktúra, és a folyamatos mozgásban lévő beszállítói ökoszisztémához, valamint a gyorsan változó vásárlói igényekhez proaktívan alkalmazkodni képes múködési modell nélkül. A helyes üzleti modellezés kiterjeszti a döntéshozók perspektíváját, meghaladja a vállalkozás aktuális határait, és ezáltal teszi lehetôvé teljesen új termékek létrehozását vagy meglévő termékek újraértelmezését. Mindezek megvalósításához és eléréséhez az innovatív üzleti modellek és a legújabb technológiák szolgálnak eszközként. Átuitő siker és fenntartható versenyelôny a múködési stratégia, a technológiai téren végbemenô innováció, a gyártási folyamatok tudatos összehangolása, valamint a köréjük szerveződő beszállítói rendszer és ellátási lánc célirányos kiépítésével érhető el.

A dolgozat bemutatta, milyen szerepet tölt be az innovációs értéklánc az ötletek termékké fejlesztésében és azok piacra vitelében. Részletezte az innovációs stratégia fontosságát és felhívta a figyelmet a saját kézben tartott gyártási folyamat, a hatékonyan szervezett ellátási rendszer és a megújulási képesség közötti szoros kapcsolatra. A felvetéseket, valamint az új piacok felfedezésének és meghódításának egy lehetséges módját pedig technológiai nagyvállalatok példáin keresztül szemléltette.

A technológiai fejlődés egyre gyorsabb, ami az üzleti múködést komoly alkalmazkodási feladat elé állítja. A sikeres innováció feltételezi a fogyasztók, a környezet és a napi múködés alapos ismeretét, és ezáltal segíti hozzá a vállalkozásokat a fenntartható stratégiai versenyelőnyhöz. A következő évtizedben a szúk keresztmetszetet és az üzleti kihívást nem a technológiai fejlődés, hanem a változásokhoz történô alkalmazkodás fogja jelenteni. Azok a vállalkozások lesznek a jövő sikertörténetei, amelyek a leggyorsabban lesznek képesek üzleti stratégiájukat és múködésüket a megváltozott körülményekhez igazítani.

\section{Felhasznált irodalom}

Adner, R. (2006): Match Your Innovation Strategy Your Innovation Ecosystem. Harvard Business Review, április

Anthony, S. D. - Eyring, M. - Gibson, L. (2006): Mapping Your Innovation Strategy. Harvard Business Review, május: 1-9. o.

Cash, J.I. - Earl, M.J. - Morison, R. (2008): Teaming Up to Crack Innovation and Enterprise Integration. Harvard Business Review, november: 1-11. o.

Cole, R.E. (2011): What Really Happened to Toyota. MIT Sloan Management Review, 2011. nyár (52/4): 28-35. o.

Czégeni I. (2013): Beindult a hengermú. IT-People, július: 28. o.

Denning, S. (2012): Why Apple And GE Are Bringing Back Manufacturing. Forbes, július, letöltve: http://www. forbes.com/sites/stevedenning/2012/12/07/why-appleand-ge-are-bringing-manufacturing-back/, 2013. június 9 .

Dobák M. - Hortoványi L. - Szabó Zs. R. (2012): A sikeres növekedés és innováció feltételei. Vezetéstudomány, XLIII. évf. 12. szám: 40-48. o.

Fisher, M.L. (1997): What is the Right Supply Chain for Your Product? Harvard Business Review, márciusáprilis: 105-116. o.

Hammer, M. (2004): Deep Change. How Operational Innovation Can Transform Your Company. Harvard Business Review, április: 84-93. o. 
Hansen, M.T. - Birkinshaw, J. (2007): The Innovation Value Chain. Harvard Business Review, június: 1-12. o.

Hayes, R.H. - Pisano, G.P. (1994): Beyond World-Class: The New Manufacturing Strategy. Harvard Business Review, január-február: 77-86. o.

Hámori B. (2012): Tanulás és innováció - Elméleti dilemmák és gyakorlati nézôpontok. Vezetéstudomány, XLIII. évf. 11. szám: 2-18. o.

Hoffer I. - Katona V. (2012): Fogalmi kapaszkodók a KKV-k innovációs gyakorlatában. Vezetéstudomány, XLIII. évf. 9. szám: 46-58. o.

Kaplan, R.S. - Norton, D.P. (2008): Mastering the Management System. Harvard Business Review, január: 62-77. o.

Kim, W.C. - Mauborgne, R. (1997): Value Innovation. The Strategic Logic of High Growth. Harvard Business Review, január-február: 103-112. o.

Kiss J. (2005): A magyar vállalatok innovációs tevékenysége. Versenyképesség-kutatások múhelytanulmány-sorozat, 14. sz. múhelytanulmány. Budapest: Budapesti Corvinus Egyetem Vállalatgazdaságtan Intézet Versenyképesség Kutató Központ: 1-34. o.

Kotter, J.P. (2012): Accelerate! Harvard Business Review, nov. McAfee, A. - Brynjolfsson, E. (2012): Big Data: The Management Revolution. Harvard Business Review, október: 1-9. o.

Narayanan, V.G. - Raman, A. (2004): Aligning Incentives in Supply Chains. Harvard Business Review, november: 94-102. o.

Osterwalder, A. - Pigneur, Y. (2010): Business Model Generation. Chichester: Wiley

Pakucs J. - Papanek G. (2006): Az innovációs folyamatok szervezése. Budapest: Magyar Innovációs Szövetség

Pisano, G.P. - Shih, W.C. (2009): Restoring American
Competitiveness. Harvard Business Review, júliusaugusztus: 114-125. o.

Pisano, G.P. - Shih, W.C. (2012): Does America Really Need Manufacturing? Harvard Business Review, március: 94-102. o.

Porter, M.E. - Rivkin, J.W. (2012): The Looming Challenge to U. S. Competitiveness. Harvard Business Review, március: 55-62. o.

Porter, M.E. (1985): Competitive Advantage: Creating and Sustaining Superior Performance. Boston: Harvard University Press

Porter, M.E. (1996): What is strategy? Harvard Business Review, november-december: 59-78. o.

Rawson, C. (2012): Why Apple's products are 'Designed in California' but 'Assembled in China'. http://www. tuaw.com/2012/01/22/why-apples-products-are-designedin-california-but-assembled/, tuaw.com, január, letöltve: 2013. június 8 .

Schulz, J. - Weiss, B. (2011): Innovating on the Cheap. Harvard Business Review, június: 88-94. o.

Stalk, G. Jr. - Webber, A.M. (1993): Japan's Dark Side of Time. Harvard Business Review, július-augusztus: 93 102. 0.

Vörös, J. (2006): The Dynamics of Price, Quality and Produtivity Imporovement Decisions. European Journal of Operational Research: 809-823. o.

Vörös, J. (2010): Termelés- és szolgáltatásmenedzsment. Budapest: Akadémiai Kiadó

Wheelwright, S.C. - Hayes, R.H. (1985): Competing Through Manufacturing. Harvard Business Review, január-február: 93-103. o.

Wise, R. - Baumgartner, P. (1999): Go Downstream. The New Profit Imperative in Manufacturing. Harvard Business Review, szeptember-október: 133-141. o. 